\title{
Prokaryotic picoplankton distribution within the oxygen minimum zone of the central Mexican Pacific across environmental gradients
}

\author{
Zuleima Santana-Vega ${ }^{1}$, David Uriel Hernández-Becerril ${ }^{*}$, Alejandro R. Morales-Blake ${ }^{2}$, \\ Francisco Varona-Cordero ${ }^{I}$, Martín Merino-Ibarra ${ }^{1}$
}

\author{
${ }^{1}$ Instituto de Ciencias del Mar y Limnología - Universidad Nacional Autónoma de México \\ (Ciudad Universitaria, Coyoacán, México, D.F. 04510) \\ ${ }^{2}$ Facultad de Ciencias Marinas - Universidad de Colima \\ (Manzanillo, Colima 28868, Mexico)
}

*Corresponding author: dhernand@cmarl.unam.mx

\section{ABSTRACT}

Marine picophytoplankton has become an important issue to understand the global ecology of phototrophic forms, due to its wide distribution and contribution to biomass and productivity. We studied the abundance, distribution and signature pigments of the prokaryote picophytoplankters Prochlorococcus and Synechococcus during an oceanographic cruise (26 April to 7 May, 2011) in the central Mexican Pacific, a relatively poorlyknown oxygen minimum zone (OMZ), and the effect of three environmental gradients. Prochlorococcus and Synechococcus abundances were comparable with those found in other tropical areas ( 0.17 to $30.37 \times 10^{4}$ cells $\mathrm{mL}^{-1}$, and 0.9 to $30.97 \times 10^{4}$ cells $\mathrm{mL}^{-1}$, respectively). Prochlorococcus abundances reached highest numbers in deeper waters, often coinciding with the second deep in situ fluorescence (and chlorophyll $\alpha$ ) maxima, at oceanic stations, below the nitratecline, whereas Synechococcus abundances were higher at subsurface waters and its concentration maxima usually coincided with the subsurface in situ fluorescence maxima, with slightly higher abundances in coastal stations. Statistical analyses support significantly these results. Distribution of divinyl-chlorophyll $\alpha$ was erratic along the water column and occasionally coincided with the deep in situ fluorescence maxima, whereas the distribution of zeaxanthin usually followed that of chlorophyll $\alpha$ and the abundances of Synechococcus, and peaked together. These results are similar to those previously found in the study area and in more temperate zones, and also to the general trend in OMZ, but confirm that the second deep chlorophyll $\alpha$ maxima are attributed to high Prochlorococcus densities. We additionally found the abundance and distribution of Prochlorococcus and Synechococcus strongly driven by the environmental gradients observed.

Descriptors: Mexican Pacific, Oxygen minimum zone, Prochlorococcus, Prokaryote picophytoplankton, Synechococcus.

Submitted on: 28/July/2017

Approved on: 11/March/2018

http://dx.doi.org/10.1590/S1679-87592018004806602

\section{RESUMO}

O picophytoplankton marinho tornou-se uma questão importante para compreender a ecologia global das formas fototróficas, devido à sua ampla distribuição e contribuição para a biomassa e a produtividade. Estudamos os pigmentos de abundância, distribuição e assinatura do picofitoplâncton procarionte Prochlorococcus e Synechococcus durante um cruzeiro oceanográfico no Pacífico central mexicano, uma zona mínima de oxigênio relativamente poco conhecida (OMZ) e o efeito de três gradientes ambientais. As abundâncias de Prochlorococcus e Synechococcus foram comparáveis às encontradas em outras áreas tropicais ( 0.17 to 30.37 X 104 células mL1, e 0.9 to 30.97 X 104 células mL-1, respectivamente). As abundâncias de Prochlorococcus atingiram o maior número em águas mais profundas, coincidindo frequentemente com a segunda intensidade de fluorescência in situ profunda (e clorofila a), em estações oceânicas, abaixo da nitratoclina, enquanto as abundâncias de Synechococcus foram maiores nas águas de subsuperficie e sua concentração máxima geralmente coincidiu com os máximos de subsuperficie de fluorescência in situ, com abundâncias ligeiramente mais altas nas estações costeiras. As análises estatísticas suportam significativamente esses resultados. A distribuição da divinil-clorofila a foi errática ao longo da coluna de água e coincidiu ocasionalmente com os máximos de fluorescência in situ profundos, enquanto que a distribuição da zeaxantina seguiu geralmente a da clorofila a e as abundâncias de Synechococcus e atingiu o pico. Estes resultados são semelhantes aos encontrados anteriormente na área de estudo e em zonas mais temperadas, e também à tendência geral na OMZ, mas confirmam que a clorofila profunda a maxima é atribuída a altas densidades de Prochlorococcus. Além disso, encontramos a abundância e distribuição de Prochlorococcus e Synechococcus fortemente conduzida pelos gradientes ambientais observados.

Descritores: Pacífico Mexicano, Prochlorococcus, Picofitoplâncton procariote, Synechococcus, Zona mínima de oxigênio. 


\section{INTRODUCTION}

Marine picophytoplankton (less than $2 \mu \mathrm{m}$ in size) are important a very important issue to understand the global ecology of phototrophic forms and may contribute up to $70 \%$ of the phytoplankton biomass and productivity, and can dominate in tropical, subtropical and oligotrophic waters worldwide (Fogg, 1986, 1995; Raven, 1998; Partensky et al., 1999; Buitenhuis et al., 2012). Picophytoplankton is constituted by both eukaryotes and prokaryotes, being the coccoid unicellular picocyanobacteria Synechococcus and Prochlorococcus the smallest and most widespread phototrophic organisms in the planet (Scanlan and West, 2002; Buitenhuis et al., 2012; Massana and Logares, 2013; Biller et al., 2015).

The genera, Synechococcus and Prochlorococcus, are closely related and may coexist in the oceanic habitats, but they may occupy different niches, ecotypes and clades (Scanlan and West, 2002; Ting et al., 2002; Bouman et al., 2006; Biller et al., 2015). These differences are mainly related to three features: temperature restrictions, differential photosynthetic light-harvesting system, and differential assimilation of nutrients, particularly sources of nitrogen (Palenik, 2001; Ting et al., 2002; Rocap et al., 2003). Thus, it is evident that environmental gradients of light, nutrients and temperature play a key role in determining picocyanobacteria community structure, especially in vertical profiles of the water column (Fuller et al., 2006).

In Mexican waters, the first insight of the importance of the picophytoplankton to total phytoplankton biomass and productivity was most possibly a study conducted in the Gulf of California by Berman (1975). A pioneer evaluation of the abundance and distribution of Synechococcus in the Mexican Pacific was made by Díaz and Maske (2000), whereas considerably high densities of Prochlorococcus were detected deeper than an oxygen minimum layer, in the tropical Mexican Pacific (in front of Acapulco) by Goericke et al. (2000). More recently, Lara-Lara and Bazán-Guzmán (2005) found a variable and yet important contribution of the picophytoplankton to the biomass and primary production in waters from the Mexican Pacific, then followed by analysis of the prokaryote biomass (Prochlorococcus and other cyanobacteria) and its contribution to the total phytoplankton chlorophyll $\alpha$, which reached between 60 $80 \%$ in the tropical Mexican Pacific (Almazán-Becerril and García-Mendoza, 2008) and approximately $70 \%$ in the western coasts off Baja California, Mexican Pacific (Almazán-Becerril et al., 2010). Also, in the southern Gulf of Mexico, the general structure of the photosynthetic picophytoplankton (both prokaryotes and eukaryotes) was studied using different protocols and approaches such as epifluorescence and transmission electron microscopy, flow cytometry, biomarker photosynthetic pigments and molecular probes, and its relationship with environmental conditions (Hernández-Becerril et al., 2012; Aquino et al., 2013).

The Oxygen Minimum Zones (OZM's) are certain areas of the oceans which have a very low concentration of Dissolved Oxygen very close to surface. One important area is the Eastern North Pacific (ENP). It was recently hypothesized that OMZ's are going to spread in the coming decades as a consequence of global climate change and that are also keys to understanding the present unbalanced nitrogen cycle and the oceans' role on atmospheric greenhouse control (Paulmier and Ruiz-Pino, 2009). The central part of the Mexican Pacific (e.g. between the entrance to the Gulf of California to the most northern limit of the Gulf of Tehuantepec) is situated in the Eastern Tropical North Pacific (ETNP) and has been poorly characterized. Paulmier and Ruiz-Pino (2009) mentioned that the ETNP is one the less known OZM areas. In other areas of the world with an OMZ (off Chilean waters) the genus Prochlorococcus forms a deep chlorophyll $\alpha$ maximum (Lavin et al., 2010; Ulloa et al., 2012).

In this study, recognition, abundance and distribution of the prokaryotic picophytoplankton are investigated in the first time for the central Mexican Pacific, located within an oxygen minimum zone (OMZ), where previous studies (Cepeda-Morales et al., 2009) had detected recurrent deep chlorophyll maximum layers in oceanic stations, which were unempirical attributed to high Prochlorococcus populations. We also provide information on the differential distribution (from the coast to the ocean, latitudinal and vertical) of Synechococcus and Prochlorococcus and their pigment signatures across environmental gradients.

\section{MATERIAL AND METHODS}

\section{STUDY AREA}

This study was conducted in an area of the tropical central Mexican Pacific, between $16^{\circ} 20.421$ and $20^{\circ} 27.500 \mathrm{~N}$, and $100^{\circ} 02.922$ and $106^{\circ} 15.052 \mathrm{~W}$ (Figure 1). This area harbors a great diversity of organisms 
and important pelagic fisheries, enhanced by different mechanisms of natural fertilization such as mesoscale phenomena (plumes and eddies) and upwellings, and shallow thermoclines reducing stratification and keeping relatively high phytoplankton biomass values (LópezSandoval et al., 2009). Another interesting point is that this area is located within an oxygen minimum zone (Paulmier and Ruiz-Pino, 2009; Ulloa et al., 2012), and some hydrographic features might affect the vertical distribution of biological properties such as chlorophyll $\alpha$ (Cepeda-Morales et al., 2009).

\section{HYDROGRAPHIC DATA AND WATER SAMPLING}

Samples were collected at forty-seven fixed stations during the oceanographic cruise "MareaR III", carried out from 26 April to 7 May 2011, on board the R/V "El Puma", considering five zones: Cabo Corrientes (CC), Jalisco, Bays of Manzanillo-Santiago (BMS), Colima, Maruata (MAR) and Lázaro Cárdenas (LC), Michoacán, and Acapulco (ACA), Guerrero (Figure 1). Seawater and hydrographic data (temperature, salinity and dissolved oxygen) were obtained in vertical profiles using a CTDRosette system with 10-L Niskin bottles (Seabird SBE 911 Plus), fitted with an additional sensor of fluorescence (Wet Labs ECO-AFL/FL). Transects perpendicular to the coastline of three to five stations were set for each of the five zones (Figure 1). Five sampling depths (usually $5,20,30,40$ and 70 or $100 \mathrm{~m}$ ), according to the in situ fluorescence (chlorophyll $\alpha$ ) maximum layers or peaks: (A) for picoplankton analysis, $4.5 \mathrm{~mL}$ were transferred in cryovials and fixed with $1 \%$ glutaraldehyde, (B) for phytoplankton pigments, $1 \mathrm{~L}$ was filtered with a vacuum pump through GF/F (47 mm diameter) membranes, (C) for discrete measurements of chlorophyll $\alpha$, an additional $1 \mathrm{~L}$ was filtered with a vacuum pump and added few drops of $\mathrm{MgCO}_{3}$. Samples (A), (B) and (C) were stored in liquid Nitrogen or in a $-20^{\circ} \mathrm{C}$ freezer, and (D) for nutrient analysis, $20 \mathrm{~mL}$ were held in polypropylene containers, after filtration with 0.45 and $0.22 \mu \mathrm{m}$ (Millipore ${ }^{\mathrm{TM}}$ type HA) nitrocellulose membranes, and kept frozen $\left(-4^{\circ} \mathrm{C}\right)$. Information on remote sensing was obtained from NASA Ocean Biology (OB. DAAC), MODIS Ocean Color Data (https://earthdata.nasa.gov/about/daacs/daac-obdaac, accessed on 2016/07/07).

\section{LABORATORY ANALYSIS}

In order to recognize and quantify picophytoplankton populations, flow cytometry analyses were conducted, following the protocol of Marie et al. (1999). Water samples were thawed at room temperature and then

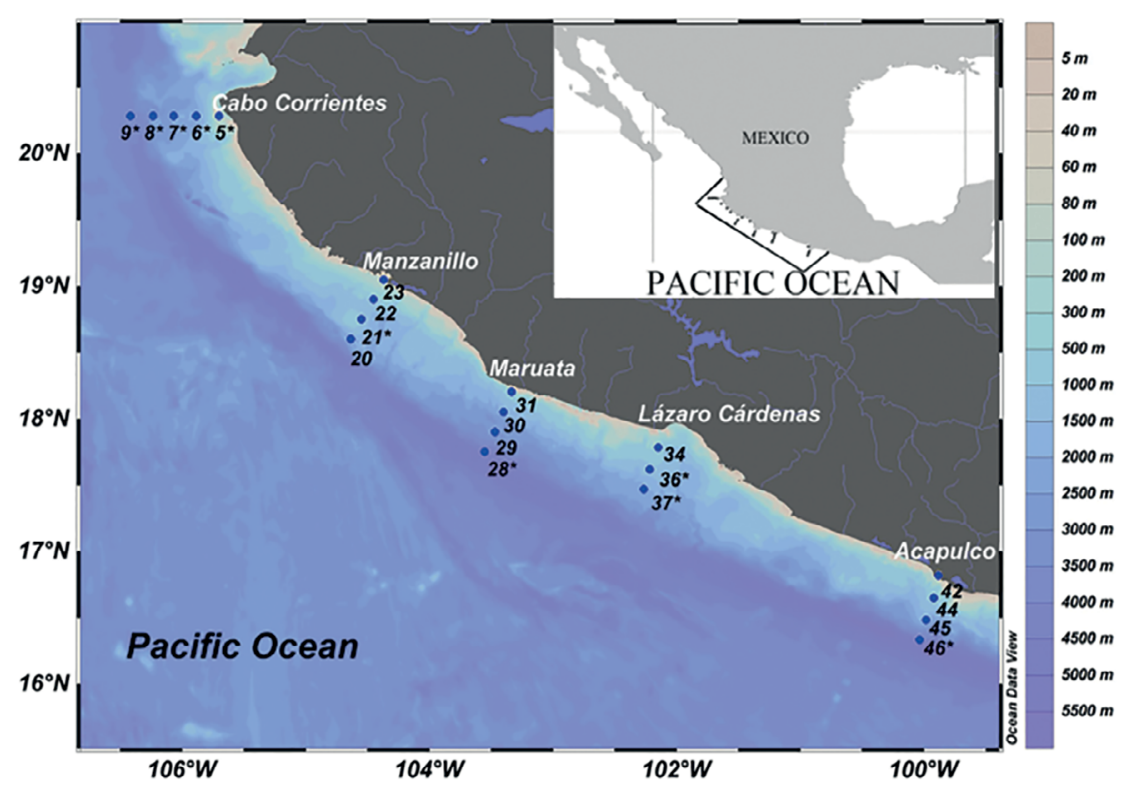

Figure 1. Map of the study area, showing the sampling stations along transects in five zones. Stations represented in vertical profiles of various physical-chemical and biological variables are marked with asterisks. 
injected into a FACSCalibur (Becton Dickinson) flow cytometer. The following parameters were considered: forward light scatter (FSC, E01), side light scatter (SSC, 450), and four fluorescences (FL1, 650 green, FL2, 650 orange, FL3, 650 red and FL4, 650 red). Additionally, 0.95 and $2.0 \mu \mathrm{m}$ fluorescent microspheres (Becton Dickinson) were used for calibration. Picophytoplankton populations were identified and quantified by analyzing all cytograms using the software Cyflogic 1.2.1.

Phytoplankton pigments were analyzed by reversephase HPLC (Waters 2695), following the proposals of Vidussi et al. (1996), once the pigment extraction in $90 \%$ acetone was made with the aid of filter trituration and clarified by centrifugation. We used a reverse-phase C8 column (RP-C8, Waters Sunfire), and two mobile phases: A (70:30, methanol: $0.5 \mathrm{~N}$ ammonium acetate, aq.), and $\mathrm{B}$ (methanol), initially $75 \% \mathrm{~A}$ and $25 \% \mathrm{~B}$, then from 1 minute $50 \%$ of $\mathrm{A}$ and $\mathrm{B}$, and then changed to $0 \% \mathrm{~A}$ and $100 \% \mathrm{~B}$ in 15 minutes, followed by the initial proportion $75 \% \mathrm{~A}$ and 25\% B in minute 19 (Vidussi et al., 1996). $200 \mu \mathrm{L}$ of each extract was injected to the HPLC system. Only the pigments divinyl chlorophyll $\alpha$ (specific pigment for Prochlorococcus) and zeaxanthin (marker pigment for Synechococcus) (Jeffrey et al., 1997) were considered and quantified in this study. Standards of these two pigments were obtained from DHI Lab Products (Hoersholm, Denmark).

Chlorophyll $\alpha$ was extracted from filters using 4 $\mathrm{mL}$ of acetone, kept at $4^{\circ} \mathrm{C}$ during $24 \mathrm{~h}$, centrifuged to recover the supernatant. Subsamples were analyzed by a spectrophotometer at absorbances 750, 665, 664, 647, 645 and $630 \mathrm{~nm}$, and then appropriate calculations of its concentration were calculated following Jeffrey and Humphrey's (1975) equations.

Nutrients samples were analyzed on a Skalar San Plus II segmented-flow continuous auto-analyzer, using the standard nutrient methods as adapted by Grasshoff et al. (1983) and the circuits suggested by Kirkwood (1994).

\section{DATA ANALYSIS}

Sampling map was generated using Ocean Data View (version 4.7.10) with the DIVA algorithm for variable resolution in a rectangular grid. (Schlitzer, 2016). Multivariate analyses were performed in order to detect spatial differences in the abundances of the prokaryotic picophytoplankton, and also to evaluate the contribution of each taxon to the spatial variability. Bray-Curtis similarity indices were calculated, after treatment of the original values (squared roots transformation), and then used to generate a non-metric multi-dimensional scaling (nMDS) analysis, in combination with a Cluster grouping analysis based on the unweighted pair group method (Clarke and Warwick, 2001). Both nMDS and Cluster analyses were performed using software Primer 6.1.4 (Clarke and Gorley, 2006). Additionally, a Spearman's correlation analysis was performed to assess the association between environmental variables and abundances of prokaryotic picophytoplankton and was represented in a correlogram, for this we used the online software of Kassambara (2016).

\section{RESULTS}

\section{HYDROGRAPHY AND OCEANOGRAPHIC CONDITIONS}

The general hydrographical conditions showed a conspicuous gradient from the north zone (CC) to the south zone (ACA). Surface water was colder (about $24^{\circ}$ C) in the north zone than in the south zones (at station 46 surface temperature was close to $30^{\circ} \mathrm{C}$ ), and surface chlorophyll $\alpha$ was associated to the SST distribution, with higher concentrations in the northern zone (Figures 2A, $\mathrm{B})$. Shallower thermoclines in the northern zones were located below or at $20 \mathrm{~m}$ depth (CC and BMS) (Figures 3,4 , Table 1), whereas thermoclines were deeper (up to $30 \mathrm{~m}$ ) in the south zones (LC and ACA) (Figure 4, Table 1). Dissolved oxygen followed a similar pattern to the thermoclines: surface concentrations decreased very quickly within the first $20 \mathrm{~m}$ depth in the north zone (CC), but the oxycline was deeper towards to south zones, notably at stations 36 (LC) and 46 (ACA) (Figures 3, 4). Additionally, concentrations of $\mathrm{NO}_{3}$ were low in surface layers but increased rapidly (nutriclines) at approximately $20 \mathrm{~m}$ depth in the north zone (stations 6 and 8, situated in $\mathrm{CC}$ ), but at about $40 \mathrm{~m}$ depth in south (stations 28, 36 and 46) (Figures 3, 4, Table 1). Values and distribution of salinity did not change considerably and they are not shown.

All subsurface fluorescence maxima were located below the main thermoclines, although they were very variable: ranging from $10-15 \mathrm{~m}$ depth in the $\mathrm{CC}$ zone, about 18-28 $\mathrm{m}$ depth in the BMS zone, between 20 and 30 $m$ depth in MAR, around 25-40 m depth in LC zone, and between 28 and $40 \mathrm{~m}$ depth in ACA (Figures 3, 4). In more oceanic stations (stations 9, 21, 28, 37 and 46) and few intermediate stations (station 6, CC), deep fluorescence maxima were detected, almost all of them having less concentration than the subsurface ones (less than $15 \%$ 


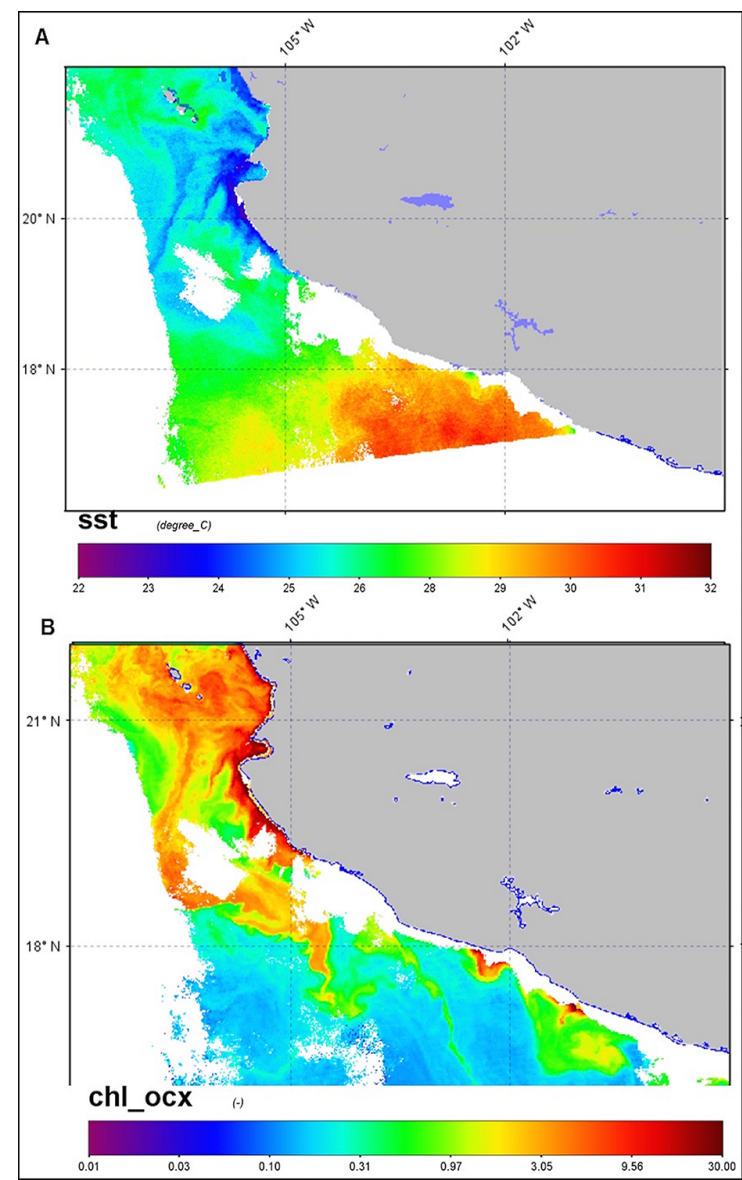

Figure 2. A. Spatial patterns of remote sensed Sea Surface Temperature (SST), and B. Chlorophyll $\alpha$ (MODIS-Aqua), for day 28-04-11, cloudy areas are colored in white.

of those), except at station 28 , where the deep maximum is nearly $80 \%$ the concentration of the subsurface one (Figure 4). Discrete measurements of chlorophyll $\alpha$ followed the vertical distribution of in situ fluorescence profiles, and their maxima were located at about the same depth of that of the fluorescence maxima (Figures 3,4).

Transects of the five zones also support the different hydrographic and oceanographic conditions found in the study area. The isotherm of $25^{\circ} \mathrm{C}$ raised close to coast, at station 6 in the zone $\mathrm{CC}$ (Figure 5A), whereas the isotherm of $26^{\circ} \mathrm{C}$ also raised close to the coast, at station 23 in the zone BMS (Figure 5B), both indicating weak upwellings, these two transects are located in the north portion of the study area. The transect of MAR (Figure 5C) showed an oceanographic structure with a nucleus of warm water (isotherm of $29^{\circ}$ C) concentrated within stations 29 and 30, where the presence of an oceanographic eddy is believed to occur. The other two transects ( $\mathrm{LC}$ and especially ACA) appeared more stable, with well-stratified water up to $40 \mathrm{~m}$ depth (Figures 5D, E). On the other hand, the concentration of chlorophyll $\alpha$ indicated by the in situ fluorescence, diminished considerably from north (CC) to south (ACA) zones, always showing maximum concentrations in coastal areas, at subsurface, and deeper high concentrations in more oceanic areas (Figures 5A-E).

\section{PROKARYOTE PICOPHYTOPLANKTON ABUNDANCES} AND DISTRIBUTION

Total cell densities of both Prochlorococcus and Synechococcus were calculated from "populations" having slightly dissimilar features in flow cytometry (Supplementary Figure 1), and ranged from 0.17 to $30.37 \times 10^{4}$ cells $\mathrm{mL}^{-1}$, and 0.9 to $30.97 \times 10^{4}$ cells $\mathrm{mL}^{-1}$, respectively (Table 1 ). The maximum density of Prochlorococcus was detected at station 7 at $74 \mathrm{~m}$ depth (CC), whereas of Synechococcus was found in station 34 at $20 \mathrm{~m}$ depth (LC).

The distribution of Prochlorococcus and Synechococcus densities was very variable and changed with latitude, proximity to the coast, and through the water column.

General tendencies of Prochlorococcus abundances were: highest densities found in north zones (CC and BMS) which were decreasing toward the south zones (M, LC and ACA) (Table 1, Figures 5A-E), highest abundances towards more oceanic stations (Figures 5A-E), and highest densities lower than $30 \mathrm{~m}$ depth (commonly between 75 and $110 \mathrm{~m}$ depth, especially in oceanic stations, although there is one exception) (Figures 3,4). On the other hand, Synechococcus abundances followed a general pattern of being higher at surface and subsurface layers and lower with depth.

The vertical distribution of Prochlorococcus and Synechococcus densities was very variable, although four general patterns were observed: (1) Highest densities of Prochlorococcus in deeper layers $(75 \mathrm{~m}$ at station 8 and $50 \mathrm{~m}$ at station 9) and Synechococcus abundances maxima found in surface layers (first $6 \mathrm{~m}$ ) in the north zone $\mathrm{CC}$ (stations 8 and 9) (Figures 3A, C), (2) Densities of Prochlorococcus increasing with depth and Synechococcus abundances maxima at $20 \mathrm{~m}$ in CC (station 6), BMS (station 21) and LC (station 31) (Figures 3C, I), (3) Prochlorococcus densities increasing with depth in MAR (stations 28 and 29), LC (station 37) and ACA (stations 44 and 46), with Synechococcus 

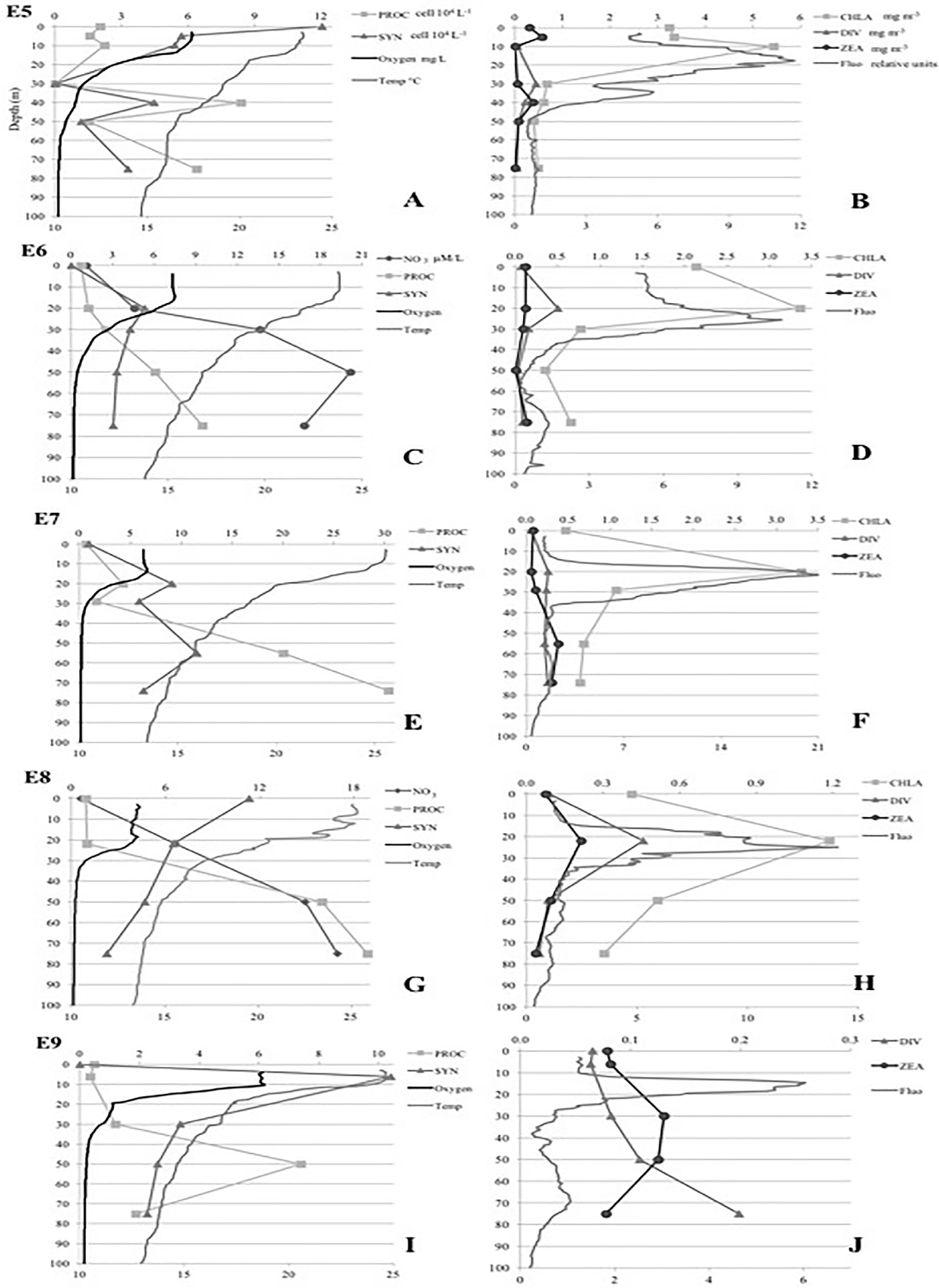

Figure 3. A, C, E, G, I. Vertical profiles of physical-chemical variables (temperature, dissolved oxygen, Nitrate concentrations) and Prochlorococcus and Synechococcus abundances. B, D, F, H, J. Vertical profiles of in situ fluorescence, chlorophyll $\alpha$, and signature pigments (divinyl-chlorophyll $\alpha$ and zeaxanthin). Stations 5 to 9 (zone CC). Units of all variables are shown in stations 5 and 6. 

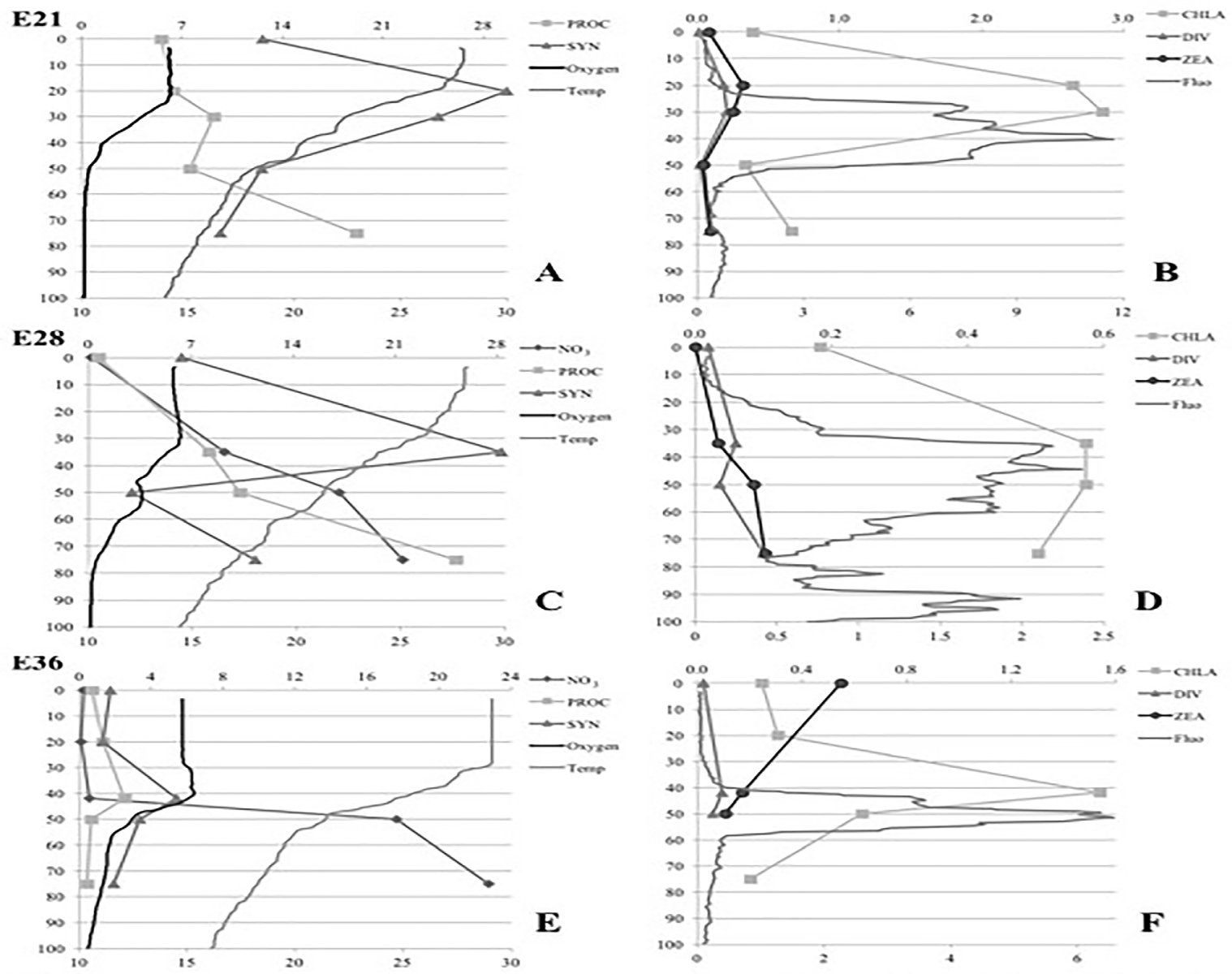

D

E37
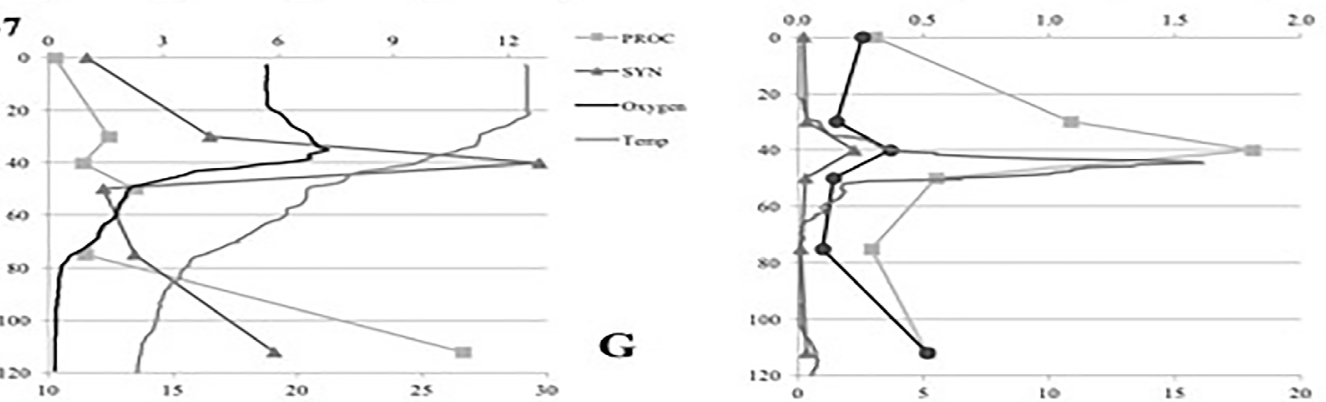

F
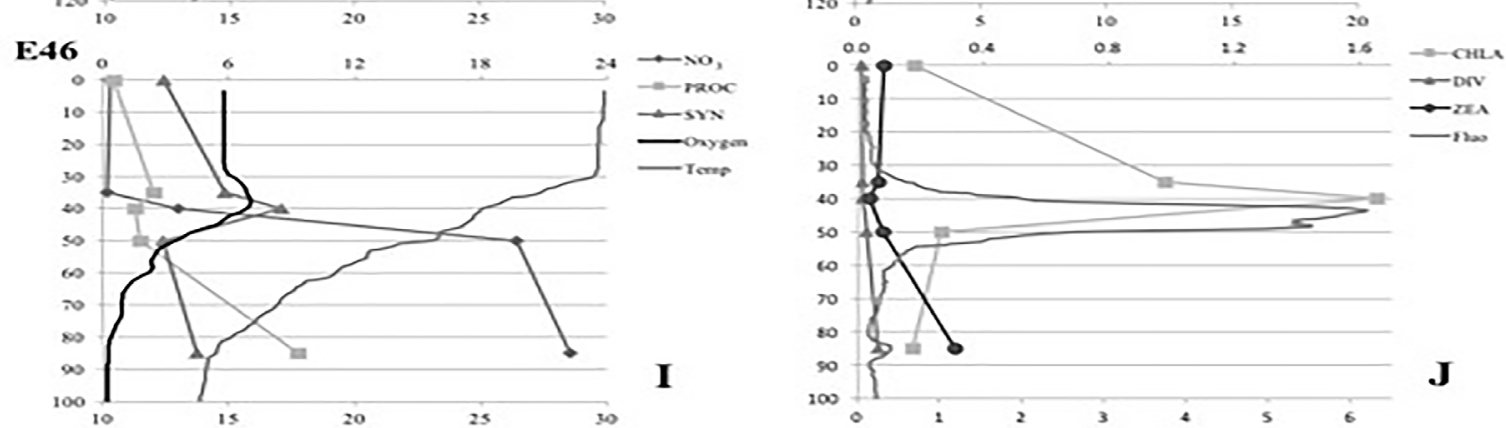

Figure 4. A, C, E, G, I. Vertical profiles of physical-chemical variables (temperature, dissolved oxygen, Nitrate concentrations) and Prochlorococcus and Synechococcus abundances. B, D, F, H, J. Vertical profiles of and in situ fluorescence, chlorophyll $\alpha$, and signature pigments (divinyl-chlorophyll $\alpha$ and zeaxanthin). Stations 21 (zone BMS), 28 (zone MAR), 36, 37 (zone LC) and 46 (zone ACA). Units as in Figure 3. 
Table 1. Hydrographic characteristics (depth of the main thermoclines and nitrateclines) and minimum-maximum intervals of signature pigments (divinyl-chlorophyll $\alpha$ and zeaxanthin) and abundances (cell numbers) of Prochlorococcus and Synechococcus found in the five zones of the study area. Zones are: $\mathrm{CC}=\mathrm{Cabo}$ Corrientes, BMS= Bahías ManzanilloSantiago, M= Maruata, LC= Lázaro Cárdenas, ACA= Acapulco.

\begin{tabular}{|c|c|c|c|c|c|c|}
\hline Variable & & $\mathrm{CC}$ & BMS & MAR & $\mathrm{LC}$ & $\mathrm{ACA}$ \\
\hline Thermocline & \multirow{2}{*}{ depth (m) } & $10-15$ & $18-20$ & $22-30$ & $25-40$ & $28-40$ \\
\hline Nitratecline & & $15-20$ & $20-25$ & $22-35$ & $30-42$ & $30-40$ \\
\hline $\begin{array}{l}\text { Divinyl- } \\
\text { chlorophyll } \alpha\end{array}$ & \multirow[t]{2}{*}{$\mathrm{mg} \mathrm{m}^{-3}$} & $0.03-0.57$ & $0.02-0.25$ & $0.01-0.27$ & $0.01-0.22$ & $0.01-0.11$ \\
\hline Zeaxanthin & & $0-0.57$ & $0-1.09$ & $0-0.29$ & $0-0.55$ & $0-0.31$ \\
\hline Prochlorococcus & \multirow{2}{*}{ x $10^{4}$ cells $\mathrm{mL}^{-1}$} & $0.36-30.37$ & $3.20-19.15$ & $0.55-25.14$ & $0.17-10.79$ & $0.53-9.30$ \\
\hline Synechococcus & & $0.90-12.06$ & $6.67-29.59$ & $1.54-28.23$ & $1.01-30.97$ & $1.50-12.05$ \\
\hline
\end{tabular}

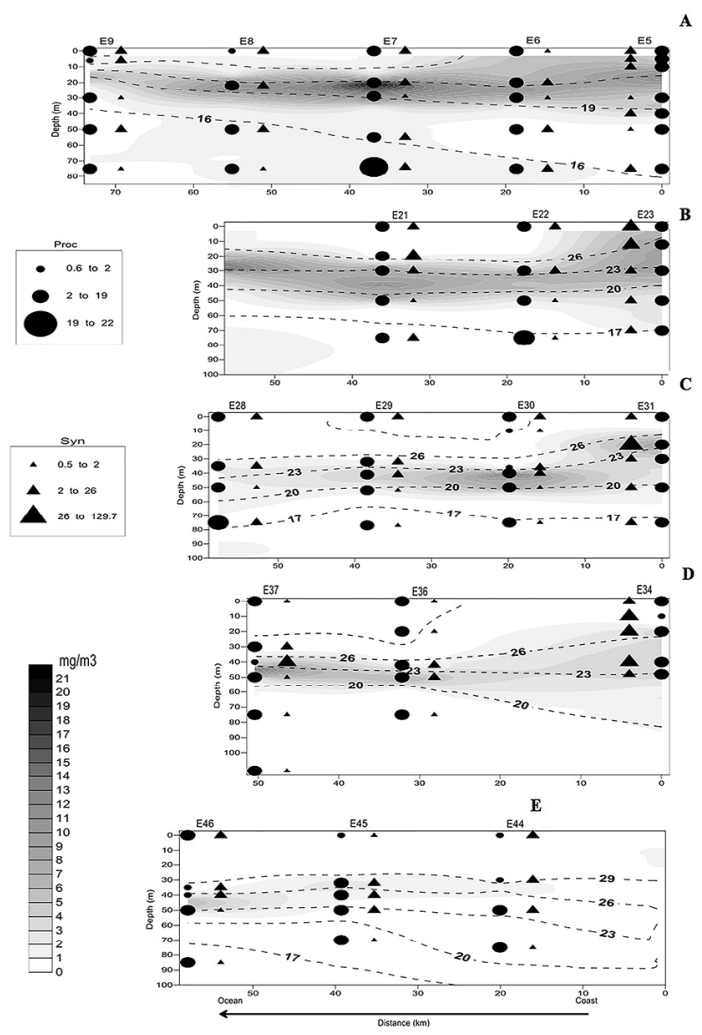

Figure 5. Transects of five zones showing distribution of isotherms, in situ fluorescence (in relative units), and Prochlorococcus (Proc) and Synechococcus (Syn) abundances. Letters denote the five zones: $\mathrm{A}=$ Cabo Corrientes, $\mathrm{B}=$ Bahías Manzanillo-Santiago, $\mathrm{C}=$ Maruata, $\mathrm{D}=$ Lázaro Cárdenas, and $\mathrm{E}=$ Acapulco.

maxima densities between 30 and $42 \mathrm{~m}$ (Figures 4C, G, I), and (4) Vertical distributions of Prochlorococcus and Synechococcus densities were similar at stations 5, 7 and 36 and in station 36 and followed chlorophyll $\alpha$ distribution at station 36, peaking at $41 \mathrm{~m}$ depth (Figures 3A, E, 4E).

\section{PhytoplanKTON PIGMENTS}

The concentrations of the signature pigments of both Prochlorococcus and Synechococcus ranged from 0.01 to $0.57 \mathrm{mg} \cdot \mathrm{m}^{-3}$ for divinyl-chlorophyll $\alpha$, and from undetectable to $1.09 \mathrm{mg} \cdot \mathrm{m}^{-3}$ for zeaxanthin. The latitudinal and vertical distributions of the signature pigments did not usually follow that of the respective Prochlorococcus and Synechococcus abundances. At station 8 (CC) the fluorescence maxima, discrete chlorophyll $\alpha$, divinyl-chlorophyll $\alpha$ and zeaxanthin coincided (22 $\mathrm{m}$ depth), whereas at the oceanic station 9 (CC), divinyl-chlorophyll $\alpha$ increased with depth and reached to a maximum concentration at $75 \mathrm{~m}$ depth coinciding with the fluorescence maximum (Figures $3 \mathrm{H}, \mathrm{J}$ ). At station 21 (BMS), divinyl-chlorophyll $\alpha$ and zeaxanthin followed a similar pattern, which was coincided with that of chlorophyll $\alpha$ (Figure 3B). At oceanic station 28 the vertical distributions of Prochlorococcus abundances and divinylchlorophyll $\alpha$ were also similar (Figure 4D). At station 37 (LC), peaks of fluorescence, discrete chlorophyll $\alpha$ and zeaxanthin coincided at $40 \mathrm{~m}$ and 110 depths (Figure $4 \mathrm{H}$ ).

\section{STATISTICAL ANALYSIS RESULTS}

The nMDS analysis, based on picophytoplankton abundances by sample, showed a reliable ( 0.08 stress value) ordination (Figures 6 A-C). This stress level corresponds to an "adequate" representation in two dimensions of the similarity of samples within and among groups (Clarke, 1993). The Cluster analysis allowed to recognize three main groups with similarity level of $75 \%$ (Figure $6 \mathrm{~A}$ ). The samples with depths with more than $50 \mathrm{~m}$ and the samples of less than $30 \mathrm{~m}$ depth constitute the first two groups, and are located in diagonal direction in the nMDS, suggesting a 


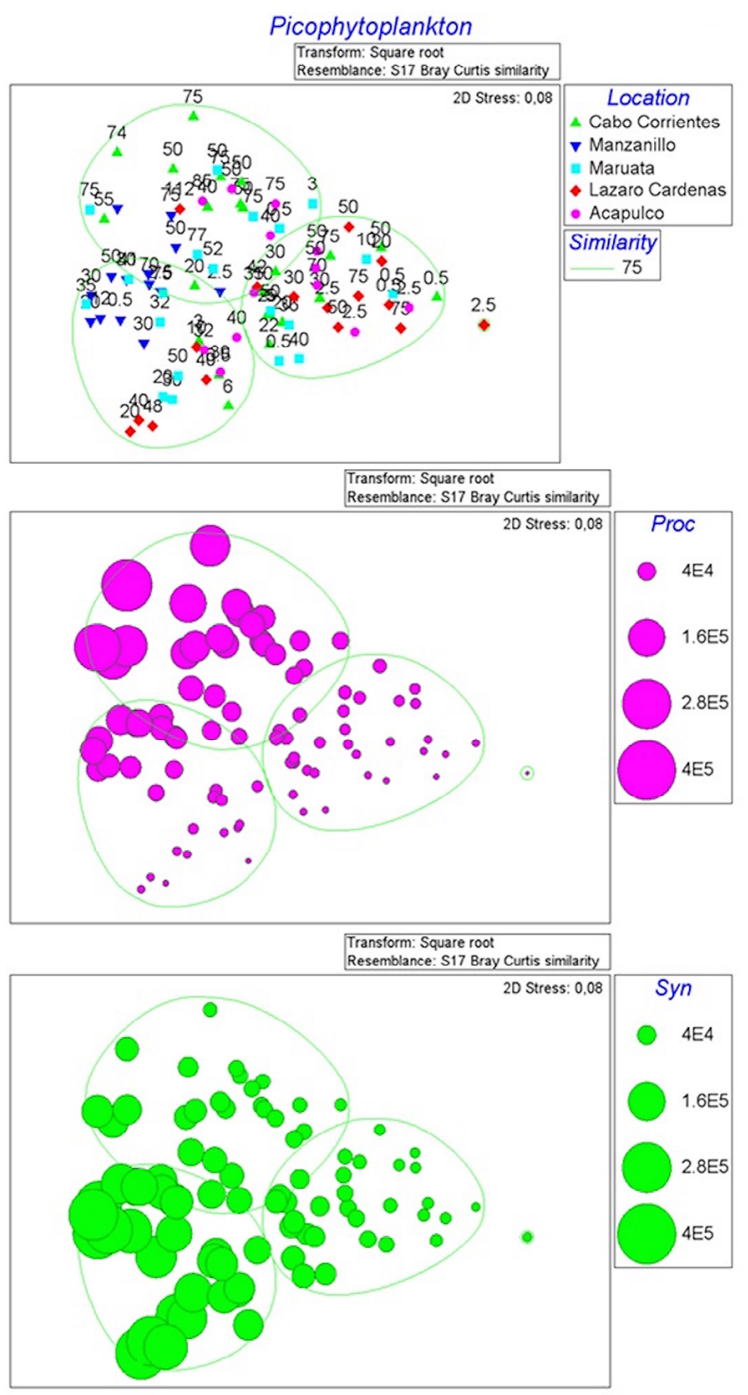

Figure 6. A. nMDS ordination of picophytoplankton coupled to a cluster analysis. B, C. Overlapping bubble plots Prochlorococcus and Synechococcus abundances, respectively. Solid lines represent the principal clusters identified a $75 \%$ of Bray Curtis similarity.

transition of the picophytoplankton superficial to a deeper community. In the third group are the samples deeper than 30 and less than $50 \mathrm{~m}$ depth. The distributions of the abundances of both Prochlorococcus and Synechococcus (Figures 6B, C) do support such results.

Spearman's correlations showed significant relationships (either positive or negative) among abundances of prokaryote phytoplankton and environmental variables (Figure 7). Prochlorococcus related significantly and negatively to the dissolved oxygen $(r=-0.64)$, temperature $(r=-0.74)$ and ammonium $(r=-0.33)$, whereas the relation was significant and positive with depth $(r=0.75)$. Conversely, Synechococcus abundances were associated

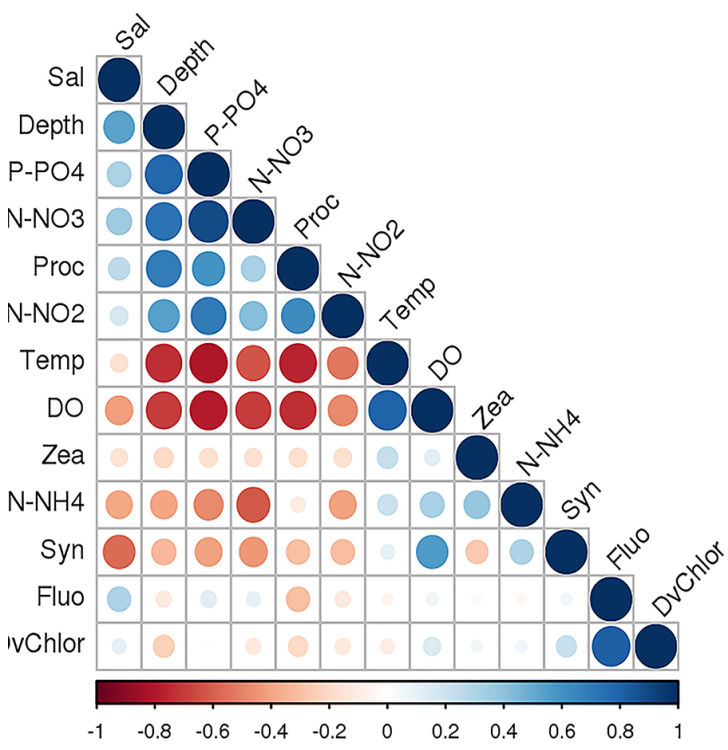

Figure 7. Spearman rank correlogram between the abundances of prokaryote picophytoplankton, signature pigments and environmental variables. Positive correlations are displayed in blue and negative in red. Color intensity and the size of the circle are proportional to the correlation coefficients.

to chlorophyll $\alpha(r=0.20)$. Other significant relationships among environmental variables were a negative correlation of temperature with nutrients $\left(\mathrm{PO}_{4}, \mathrm{NO}_{2}\right.$ and $\left.\mathrm{NO}_{3}\right)$ and a positive one with dissolved oxygen, and salinity associated negatively with dissolved oxygen $(r=0.75)$.

\section{DISCUSSION}

The hydrographic and oceanographic conditions found during this study clearly show at least three different environmental gradients. The first gradient was latitudinal (from north to south), with lower surface temperatures (Figure 2A) and shallower main "clines" (e.g. thermoclines, oxyclines and nutriclines) in the north zones (especially $\mathrm{CC}$ ), gradually lowering in depth toward to south zones (particularly ACA). The temperature gradient has been previously documented in the study area (Gallegos et al., 2006). Additionally, as the subsurface in situ fluorescence and chlorophyll $\alpha$ maxima occurred at all stations and were associated to the depth of the main thermoclines, consequently they were located deeper in the water column toward the south zone.

Another conspicuous environmental gradient was from the coast to ocean, in which not only differences in depth exist, but also some oceanographic processes occur such as weak coastal upwellings and probably one oceanographic 
eddy at intermediate stations (Figures 5A, B). The most oceanic stations also differed from the coastal ones because of the presence of a second and deep fluorescence and chlorophyll maxima. And finally, the third gradient is provided by the vertical distributions of almost all physical-chemical variables, previously described. One of the most important features of this gradient is given by dissolved oxygen concentrations (oxygen minimum zone).

Prochlorococcus and Synechococcus abundances were comparable with those found in other tropical areas, ranging from 0.17 to $30.37 \mathrm{X} 10^{4}$ cells $\mathrm{mL}^{-1}$, and 0.9 to $30.97 \times 10^{4}$ cells $\mathrm{mL}^{-1}$, respectively (Table 1 ). These numbers are similar to those found in another tropical zone, near the study area to the north (Gulf of California) (Hernández-Becerril and Pastén-Miranda, 2015) and to the south (Costa Rica Dome) (Gutiérrez-Rodríguez et al., 2014), and about exactly the same values (maxima densities ranging from $4.53 \times 10^{4}$ to $3.2 \times 10^{5}$ cells $\mathrm{mL}^{-1}$ for Prochlorococcus, and $1.19 \times 10^{5}$ to $3.8 \times 10^{5}$ cells $\mathrm{mL}^{-1}$ for Synechococcus) in tropical and subtropical zones such as East China (Guo et al., 2014), the Gulf of Mexico (Linacre et al., 2015), the Gulf of California (HernándezBecerril \& Pastén-Miranda, 2015), and the South Atlantic (Brazil) (Gérikas-Ribeiro et al., 2016; Bergo et al., 2017).

Although the presence of the prokaryotic picophytoplankton Prochlorococcus and Synechococcus populations was registered at all stations sampled (from north to south zones) and through the water column (up to $110 \mathrm{~m}$ depth in some cases), there are differential distributions which might depend on the distinct gradients observed. Their signature pigments, divinyl-chlorophyll $\alpha$ and zeaxanthin, respectively, were also found in most samples (except from few undetectable values of zeaxanthin), but were less useful in this study to explain distribution tendencies, as they did not usually correspond or follow the patterns observed in their abundances (cell numbers), although few similarities and coincidences were also found. Values of both abundances (as cell numbers) and signature pigments of Prochlorococcus and Synechococcus recorded in this study were similar to those found elsewhere, in more temperate waters (Jiao et al., 2005; Pan et al., 2005).

We were able to define general patterns in the vertical distribution of both Prochlorococcus and Synechococcus abundances: the common increase of Prochlorococcus densities deeper in the water column (up to $110 \mathrm{~m}$ depth), associated in most cases with the second, deep fluorescence and chlorophyll $\alpha$ maxima in oceanic stations, and Synechococcus abundances forming maxima at surface (0-6 m depth), or either at subsurface (around $20 \mathrm{~mm}$ depth) or lower than $30 \mathrm{~m}$, usually coinciding with the subsurface fluorescence and chlorophyll $\alpha$ maxima; similar vertical distributions were also found in the Gulf of California, where subsurface (20-30 m) maxima were detected, and one surface maximum coincident with lower temperatures, probably due to a weak upwelling (Hernández-Becerril and Pastén-Miranda, 2015).

These general distribution patterns were also confirmed by the statistical analyses performed (nMDS), which showed Prochlorococcus more abundant in deeper layers, in contrast to Synechococcus (Figures 6B, C), and the correlation among various environmental data (Figure 7). This is a distinctive feature of the study area, for the high Prochlorococcus densities have been related to the presence of a second, deep chlorophyll $\alpha$ maximum and to the minimum oxygen layer which is shallow close to the coast but becomes deeper towards more oceanic waters (Goericke et al., 2000). Additionally, in adjacent areas Almazán-Becerril and García-Mendoza (2008) found that divinyl-chlorophyll $\alpha$ constituted approximately $90 \%$ of the total chlorophyll $\alpha$ between 80 and $90 \mathrm{~m}$ depth.

Similar tendencies on the vertical distribution of Prochlorococcus and Synechococcus abundances have been also reported in other geographic areas (Uysal, 2006; Brunet et al., 2007). These patterns indicated a strong latitudinal and vertical effect caused by their environmental gradients, and a differential distribution, particularly the vertical distribution which leads to the formation of a multi-layered structure.

However, despite the recognition of the patterns in the vertical distribution, it is still possible to distinguish different Prochlorococcus populations (ecotypes ?) in the water column, especially at stations 5, 28 and 37, where higher abundances were found either at surface or subsurface, but also deeper, coinciding with the second deep fluorescence maxima. These different Prochlorococcus populations might characterize the relatively well-known ecological condition of light-adapted forms or ecotypes, some adapted to high-light (HL) and others adapted to low-light (LL) (Scanlan and West, 2002; Bibby et al., 2003; Zinser et al., 2006; Biller et al., 2015), may partially help to explain this behavior. A similar explanation may also apply to the Synechococcus populations, which might include different clades (Tai and Palenik, 2009), although we observed more stable patterns than Prochlorococcus in most stations studied here. 
Different multi-layered structures have been found in the vertical distribution of marine phytoplankton all over the world (Cullen, 2015), and especially regarding picocyanobacterial community, Fuller et al. (2006) have shown a complex spatial compartmentalization of ecotypes and clades of both Prochlorococcus and Synechococcus, and ecotypes have been also found in the world ocean (Scanlan and West, 2002; Zinser et al., 2006; Choi et al., 2011). Various physiological characteristics may count to explain these spatial distributions, particularly the vertical distribution, including differential adaptations (or ecotypes) to light intensity (HL and LL), and to uptake a wide range of Nitrogen compounds (Palenik, 2001; Scanlan and West, 2002; Ting et al., 2002; Bibby et al., 2003; Rocap et al., 2003; Zubkov et al., 1998; Veldhuis et al., 2005). The Prochlorococcus signature pigment, divinyl-chlorophyll $\alpha$, is believed to harvest more efficiently blue light (Ito and Tanaka, 2011).

The particular conditions of the deeper water layers in the study area, with very low (suboxic) dissolved oxygen concentrations, low-light intensity (with a spectral blue feature) and high nitrate concentrations may favor the formation of a second, deep fluorescence maxima, especially in oceanic areas which are produced by Prochlorococcus populations (Goericke et al., 2000). Furthermore, some particular Prochlorococcus ecotypes (or clades) known as LLV and LLVI have only been found in OMZ (Lavin et al., 2010).

Although there were previous indications of the cells aggregations in the top layer of the $\mathrm{OMZ}$ in the Eastern tropical north Pacific, where the current study area is situated, Goericke et al. (2000) did provide sufficient information to asses a poorly-studied niche of Prochlorococcus, under low-light and suboxic conditions in this area. These findings were also followed by later studies in the same area, one of which was based on both phytoplankton pigments analysis and use of CHEMTAX program to estimate Prochlorococcus contributions to the total phytoplanktonic biomass and allocated its larger biomass related to the deep fluorescence maxima (Almazán-Becerril and García-Mendoza, 2008), whereas Cepeda-Morales et al. (2009) considered that the deep fluorescence maxima in oceanic locations were produced by Prochlorococcus populations, although they did not provide any evidence (e.g. information on Prochlorococcus signature pigments or recognition and enumeration of cells). Furthermore, these potentially productive layers have not been usually considered to calculate the whole productivity in the water column within the study area (López-Sandoval et al., 2009).

Some of the correlations calculated yielded negative values between Prochlorococcus abundances and temperature, Dissolved Oxygen and $\mathrm{NH}_{4}$, and positive values with depth (Figure 7), thus indicating the preference of its populations for deeper layers, and confirming again the previous results obtained by Goericke et al. (2000) about the niche of Prochlorococcus, under lowlight and suboxic conditions in this area. Conversely, Synechococcus abundances were positively correlated with fluorescence, Dissolved Oxygen and $\mathrm{NH}_{4}$ (Figure 6), coinciding with its distribution at subsurface layers. The very low correlations between Prochlorococcus and Divinyl chlorophyll $\alpha$, and Synechococcus and zeaxanthin confirm that their distributions did not match in this study.

In this study, we provide evidence of the formation of deep fluorescence and chlorophyll maxima, especially in oceanic stations, due to the abundant populations of Prochlorococcus (and few cases high concentration of its signature pigment, divinyl-chlorophyll $\alpha$ ), corroborating that these layers are produced by Prochlorococcus, and that these formations coincided with suboxic events and high nitrate concentrations, an apparent condition of the OMZ in the study area (Goericke et al., 2000; Maske et al., 2010) and other similar areas in the world (Ulloa et al., 2012). Our results also agree with others in the world literature about abundance and distribution of Synechococcus, particularly its high cell numbers in more coastal environs and the formation of subsurface abundance maxima along the water column (Scanlan and West, 2002). The environmental gradients detected during this study are important in shaping the structure of these prokaryote picophytoplankters.

\section{ACKNOWLEDGEMENTS}

We are grateful to Elva Escobar Briones (ICMyL, UNAM) and Carlos Castellanos Barba (IIBiomédicas, UNAM) for facilities and assistance in using HPLC and flow cytometry, respectively, to Sergio Castillo Sandoval and Vladislav Carnero (ICMyL, UNAM) for guidance in using SURFER, obtaining, analyzing and providing nutrients samples and data.

\section{FUNDING}

Partial support for this study has been given by PAPIIT, DGAPA, UNAM (projects IN226209-3 and 
IN296516). Coordinación de la Investigación Científica (CIC, UNAM) approved and supported the use the R/V "El Puma". ZS-V received a fellowship from CONACYT for a M. Sc. degree.

\section{REFERENCES}

ALMAZÁN-BECERRIL, A. \& GARCÍA-MENDOZA, E. 2008. Maximum efficiency of charge separation of photosystem II of the phytoplankton community in the Eastern Tropical North Pacific of Mexico: A nutrient stress diagnostic tool? Ciencias Marinas, 34, 29-43.

ALMAZÁN-BECERRIL，A., GARCÍA-MENDOZA， E. \& RIVAS, D. 2010. Distribución de pigmentos fotosintéticos y grupos de fitoplancton durante octubre de 2003. In: Gaxiola-CASTRO, G. \& DURAZO, R. (eds.) Dinámica del ecosistema pelágico frente a Baja California 1997-2007. México: SEMARNAT, INE, CICESE and UABC.

AQUINO-CRUZ, A., HERNÁNDEZ-BECERRIL D. U., SIGNORET-POILLON M., SALAS-DE-LEÓN D. A. \& MONREAL-GÓMEZ, M. A. 2013. Studies on picophytoplankton in the southern Gulf of Mexico: recognition of picoprokaryotes and abundances of picophytoplankton during “dry season”. Brazilian Journal of Oceanography, 61, 265-276.

BERGO, N. M., SIGNORI, C. N., AMADO, A. M., BRANDINI, F. P. \& PELLIZARI, V. H. 2017. The partitioning of Carbon biomass among the pico- and nano-plankton community in the South Brazilian Bight during a strong summer intrusion of South Atlantic central water. Frontiers in Marine Science, 4, 1- 12.

BERMAN, T. 1975. Size fractionation of natural aquatic populations associated with autotrophic and heterotrophic Carbon uptake. Marine Biology, 33, 215-220.

BIBBY, T. S., MARY, I., NIELD, J., PARTENSKY, F. \& BARBER, J. 2003. Low-light-adapted Prochlorococcus species possess specific antennae for each photosystem. Nature, 424, 1051-1054.

BILLER, S. J., BERUBE P. M., LINDELL, D. \& CHISHOLM, S. W. 2015. Prochlorococcus: the structure and function of collective diversity. Nature Reviews Microbiology, 13, 13-27.

BOUMAN, H. A., ULLOA, O., SCANLAN, D. J., ZWIRGLMAIER K., LI, W. K. W., PLATT, T., STUART, V., BARLOW, R., LETH, O., CLEMENTSON, L., LUTZ, V., FUKASAWA, M., WATANABE, S. \& SATHYENDRANATH, S. 2006. Oceanographic Basis of The Global Surface Distribution of Prochlorococcus Ecotypes. Science, 312, 918-921.

BRUNET, C., CASOTTI, R., VANTREPOTTE, V., CORATO, F. \& CONVERSANO, F. 2007. Vertical variability and diel dynamics of picophytoplankton in the Strait of Sicily, Mediterranean Sea, in summer. Marine Ecology Progress Series, 346, 15-26.

BUITENHUIS, E. T., LI, W. K. W., VAULOT, D., LOMAS, M. W., LANDRY, M., PARTENSKY, F., KARL, D. M., ULLOA, O., CAMPBELL, L., JACQUET, S., LANTOINE, F., CHAVEZ, F., MACIAS, D., GOSSELIN, M. \& MCMANUS, G. B. 2012. Picophytoplankton biomass distribution in the global ocean. Earth Syst Sci Data, 4, 37-46.
CEPEDA-MORALES, J., BEIER, E., GAXIOLA-CASTRO, G., LAVÍN, M. F. \& GODÍNEZ, V. M. 2009. Efecto de la zona del mínimo de oxígeno en el segundo máximo de clorofila $a$ en el Pacífico Oriental Tropical Mexicano. Ciencias Marinas, $35,389-403$.

CHOI, D. H., NOH, J. H., HAHM, M. S., LEE, C. M. 2011. Picocyanobacterial Abundances and Diversity in Surface Water of the Northwestern Pacific Ocean. Ocean Science Journal, 46, 265-271.

CLARKE, K. R. 1993. Non-parametric multivariate analyses of changes in community structure. Austral Ecology, 18, 117143.

CLARKE, K. R. \& GORLEY, R. N. 2006. PRIMER v6: User Manual/Tutorial, Plymouth, PRIMER-E. $192 \mathrm{p}$.

CLARKE, K. R. \& WARWICK, R. M. 2001. Change in Marine Communities: an approach to Statistical analysis and interpretation, $2^{\text {nd }}$ ed. Plymouth, PRIMER-E. 172 p.

CULLEN, J. J. 2015. Subsurface chlorophyll maximum layers: enduring enigma or mystery solved? Annual Review of Marine Science, 7, 207-239.

DÍAZ, C. \& MASKE, H. 2000. Abundance of coccoid cyanobacteria, hydrographic parameters and the possible underestimation of in situ chlorophyll $\alpha$ in the northern Gulf of California and the Mexican California Current. Ciencias Marinas, 26, 441-461.

FOGG, G. E. 1986. Review Lecture: Picoplankton. Proceedings of the Royal Society B: Biological Sciences, 228, 1-30.

FOGG, G. E. 1995. Some comments on picoplankton and its importance in the pelagic ecosystem. Aquatic Microbial Ecology, 9, 33-39.

FULLER, N. J., TARRAN, G. A., YALLOP, M., ORCUTT, K. M. \& SCANLAN, D. J. 2006. Molecular analysis of picocyanobacterial community structure along an Arabian Sea transect reveals distinct spatial separation of lineages. Limnology and Oceanography, 51, 2515-2526.

GALLEGOS, A., RODRÍGUEZ R., MÁRQUEZ, E., LECUANDA，R. \& ZAVALA-HIDALGO, J. 2006. Una climatología de la temperatura de la superficie del mar de las aguas adyacentes a las costas de Jalisco, Colima y Michoacán, México: 1996-2003. In: JIMÉNEZ-QUIROZ, M. C. \& Espino-Barr E. (eds.) Los recursos pesqueros $y$ acuícolas de Jalisco, Colima y Michoacán. México: Secretaría de Agricultura, Ganadería, Desarrollo Rural, Pesca y Alimentación.

GÉRIKAS-RIBEIRO, C., LOPES DOS SANTOS, A., MARIE, D., PELLIZARI, V. H., PEREIRA BRANDINI, F. \& VAULOT, D. 2016. Pico and nanoplankton abundance and Carbon stocks along the Brazilian Bight. Peer J, 4, e2587.

GOERICKE, R., OLSON, R. J. \& SHALAPYONOK, A. 2000. A novel niche for Prochlorococcus sp. in low-light suboxic environments in the Arabian Sea and the Eastern Tropical North Pacific. Deep Sea Research Part I: Oceanographic Research Papers, 47, 1183-1205.

GRASSHOFF, K., EHRHARDT, M. \& KREMLING, K. 1983. Methods of Seawater Analysis, ${ }^{\text {ed }}$. Germany, Verlag Chemie. $419 \mathrm{p}$.

GUO, C., LIU, H., ZHENG, L., SONG, S., CHEN, B. \& HUANG, B. 2014. Seasonal and spatial patterns of picophytoplankton growth, grazing and distribution in the East China Sea. Biogeosciences, 11, 1847-1862. 
GUTIÉRREZ-RODRÍGUEZ, A., SLACK, G., DANIELS, E. F., SELPH, K. E., PALENIK, B. \& LANDRY, M. R. 2014. Fine spatial structure of genetically distinct picocyanobacterial populations across environmental gradients in the Costa Rica Dome. Limnology and Oceanography, 59, 705-723.

HERNÁNDEZ-BECERRIL, D. U., AQUINO-CRUZ, A., SALAS-DE-LEÓN, D. A., SIGNORET-POILLON, M. \& MONREAL-GÓMEZ, M. A. 2012. Studies on picophytoplankton in the southern Gulf of Mexico: pigment analysis and potential importance of the picoeukaryote Prasinophyte Micromonas pusilla. Marine Biology Research, $8,331-340$.

HERNÁNDEZ-BECERRIL，D. U. \& PASTÉN-MIRANDA, N. 2015. Abundancia y distribución de la cianobacteria picoplanctónica Synechococcus en Bahía de La Paz y Cuenca Carmen, Golfo de California (junio, 2001). Hidrobiológica, 25, 357-364.

ITO, H. \& TANAKA, A. 2011. Evolution of a divinyl chlorophyllbased photosystem in Prochlorococcus. Proceedings of the National Academy of Sciences of the United States of America, 108, 18014-18019.

JEFFREY, S. W. \& HUMPHREY, G. F. 1975. New spectrophotometric equations for determining chlorophylls $\alpha$, $b, c_{1}$ and $c_{2}$ in higher plants, algae and natural phytoplankton. Biochemie und Physiologie der Pflanzen, 167, 191-194.

JEFFREY, S. W., MANTOURA, R. F. C. \& WRIGHT, S. W. 1997. Phytoplankton pigments in oceanography: guidelines to modern methods, Paris, UNESCO Publishing.

JIAO, N., YANG, Y., HONG, N., MA, Y., HARADA, S., KOSHIKAWA, H. \& WATANABE, M. 2005. Dynamic of autotrophic picoplankton and heterotrophic bacteria in the East China Sea. Continental Shelf Research, 25, 1265-1279.

KASSAMBARA, A. 2016. Correlation Matrix - RSTHDA [online software]. Available from: http://www.sthda.com/english/ rsthda/correlation-matrix.php (last access: 4 Dec 2017).

KIRKWOOD, D. S. 1994. Sam Plus segmented flow analyzer and its applications. Seawater analysis, Breda, Skalar.

LARA-LARA, J. R. \& BAZÁN-GUZMÁN, C. 2005. Distribución de clorofila y producción primaria por clases de tamaño en la costa del Pacífico mexicano. Ciencias Marinas, 31, 11-21.

LAVIN, P., GONZÁLEZ, B., SANTIBÁÑEZ, J. F., SCANLAN D. J. \& ULLOA, O. 2010 Novel lineages of Prochlorococcus thrive within the oxygen minimum zone of the eastern tropical South Pacific. Environmental Microbiology Reports, $2,728-738$

LINACRE, L., LARA-LARA, J. R., CAMACHO-IBAR, V., HERGUERA, J. C., BAZÁN-GUZMÁN, C. \& FERREIRABARTRINA, V. 2015. Distribution pattern of picoplankton Carbon biomass linked to mesoscale dynamics in the southern Gulf of Mexico during winter conditions. Deep Sea Research Part I: Oceanographic Research Papers, 106, 55-67.

LÓPEZ-SANDOVAL, D. C., LARA-LARA, J. R., LAVÍN, M. F., ÁlVAREZ-BORREGO, S. \& GAXIOLA-CASTRO, G. 2009. Productividad primaria en el Pacífico oriental tropical adyacente a Cabo Corrientes, México. Ciencias Marinas, 35, 169-182.

MARIE, D., BRUSSAARD, C., PARTENSKY, F. \& VAULOT, D. 1999. Flow cytometric analysis of phytoplankton, bacteria and viruses. In: Current protocols in cytometry. New York: John Wiley and Sons.
MASKE, H., MEDRANO, R. C., CASTRO, A. T., MERCADO A. J., JAUREGUI, C. O. A., CASTRO, G. G. \& OCHOA, J. 2010. Inorganic carbon and biological oceanography above a shallow oxygen minimum in the entrance to the Gulf of California in the Mexican Pacific. Limnology and Oceanography, 55, 481-491.

MASSANA, R. \& LOGARES, R. 2013. Eukaryotic versus prokaryotic marine picoplankton ecology. Environmental Microbiology, 15, 1254-1261.

PALENIK, B. 2001. Chromatic adaptation in marine Synechococcus strains. Applied and Environmental Microbiology, 67, 991-994.

PAN, L. A., ZHANG, L. H., ZHANG, J., GASOL, J. M. \& CHAO, M. 2005. On-board flow cytometric observation of picoplankton community structure in the East China Sea during the fall of different years. FEMS Microbiology Ecology, 52, 243-253.

PARTENSKY, F., HESS, W. R. \& VAULOT, D. 1999. Prochlorococcus, a marine photosynthetic prokaryote of global significance. Microbiology and Molecular Biology Reviews, 63, 106-127.

PAULMIER, A. \& RUIZ-PINO, D. 2009. Oxygen minimum zones (OMZs) in the modern ocean. Progress in Oceanography, 80, 113-128.

RAVEN, J. A. 1998. The twelfth Tansley Lecture. Small is beautiful: the picophytoplankton. Functional Ecology, 12, 503-513.

ROCAP, G., LARIMER, F. W., LAMERDIN, J., MALFATTI S., CHAIN, P., AHGREN, N. A., ARELLANO, A., COLEMAN, M., HAUSER, L., HESS, W. R., JOHNSON, Z. I., LAND, M., LINDELL, D., POST, A. F., REGALA, W., SHAH, M., SHAW, S. L., STEGLICH, C., SULLIVAN, M. B., TING, C. S., TOLONEN, A., WEBB, E. A., ZINSER, E. R. \& CHISHOLM, S.W. 2003. Genome divergence in two Prochlorococcus ecotypes reflects oceanic niche differentiation. Nature, 424, 1042-1047.

SCANLAN, D. J. \& WEST, J. N. 2002. Molecular ecology of the marine cyanobacterial genera Prochlorococcus and Synechococcus. FEMS Microbiology Ecology, 40, 1-12.

SCHLITZER, R. 2016. Ocean Data View. Available from: http:// odv.awi.de (last access: 29 May 2018).

TAI, V. \& PALENIK, B. 2009. Temporal variation of Synechococcus clades at a coastal Pacific Ocean monitoring site. The ISME Journal, 3, 903-915.

TING, C. S., ROCAP, G., KING, J. \& CHISHOLM, S. W. 2002. Cyanobacterial photosynthesis in the oceans: the origins and significance of divergent light-harvesting strategies. Trends in Microbiology, 10, 134-142.

ULLOA, O., CANFIELD, D. E., DELONG, E. F., LETELIER, R. M. \& STEWART, F. J. 2012. Microbial oceanography of anoxic oxygen minimum zones. Proceedings of the National Academy of Sciences of the United States of America, 109, 15996-16003.

UYSAL, Z. 2006. Vertical distribution of marine cyanobacteria Synechococcus spp. in the Black, Marmara, Aegean, and eastern Mediterranean seas. Deep Sea Research Part II: Topical Studies in Oceanography, 53, 1976-1987.

VELDHUIS, M. J. W., TIMMERMANS, K. R., CROOT, P. \& WAGT, B. 2005. Picophytoplankton, a comparative study of their biochemical composition and photosynthetic properties. Journal of Sea Research, 53, 7-24. 
VIDUSSI, F., CLAUSTRE, H., BUSTILLOS-GUZMÁN, J., CAILLEAU, C. \& MARTY, J. C. 1996. Determination of chlorophylls and carotenoids of marine phytoplankton: separation of chlorophyll $\alpha$ from divinylchlorophyll $\alpha$ and zeaxanthin from lutein. Journal of Plankton Research, 18, $2377-2382$.
ZINSER, E. R., COE, A., JOHNSON, Z. I., MARTINY, A. C., FULLER, N. J., SCANLAN, D. J. \& CHISHOLM, S. W. 2006. Prochlorococcus ecotype abundances in the North Atlantic Ocean as revealed by an improved quantitative PCR method. Applied and Environmental Microbiology, 72, 723-732.

ZUBKOV, M. V., SLEIGH, M. A., TARRAN, G. A., BURKILL, P. H. \& LEAKEY, R. J. G. 1998. Picoplanktonic community structure on an Atlantic transect from $50^{\circ} \mathrm{N}$ to $50^{\circ} \mathrm{S}$. Deep Sea Research Part I: Oceanographic Research Papers, 45, 1339-1355. 


\section{SUPPLEMENTARY MATERIAL}
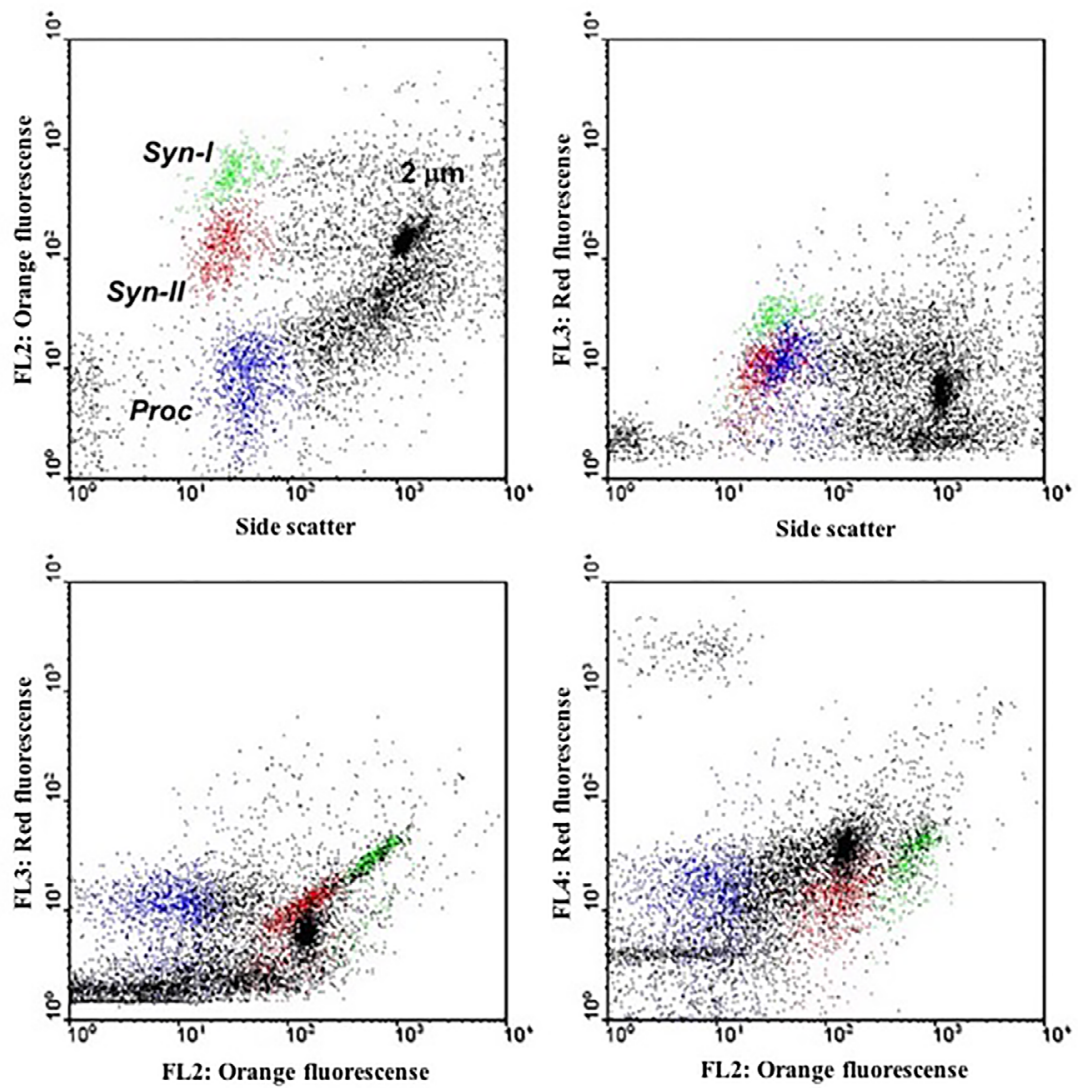

Figure 1. Flow cytometric signatures of the Prochlorococcus (Proc) and Synechococcus (Syn-I and Syn-II) populations of the station 21 (B6). The $2 \mu \mathrm{m}$ beads are also indicated. 